\title{
Bench-test comparison of 26 emergency and transport ventilators
}

Erwan L'Her ${ }^{1,2,3,4,5,6^{*}}$, Annie Roy $^{3}$ and Nicolas Marjanovic ${ }^{4}$

\begin{abstract}
Introduction: Numerous emergency and transport ventilators are commercialized and new generations arise constantly. The aim of this study was to evaluate a large panel of ventilators to allow clinicians to choose a device, taking into account their specificities of use.

Methods: This experimental bench-test took into account general characteristics and technical performances. Performances were assessed under different levels of $\mathrm{FIO}_{2}(100 \%, 50 \%$ or Air-Mix), respiratory mechanics (compliance $30,70,120 \mathrm{~mL} / \mathrm{cmH}_{2} \mathrm{O}$; resistance $5,10,20 \mathrm{cmH}_{2} \mathrm{O} / \mathrm{mL} / \mathrm{s}$ ), and levels of leaks (3.5 to $12.5 \mathrm{~L} / \mathrm{min}$ ), using a test lung.

Results: In total 26 emergency and transport ventilators were analyzed and classified into four categories (ICU-like, $\mathrm{n}=5$; Sophisticated, $\mathrm{n}=10$; Simple, $\mathrm{n}=9$; Mass-casualty and military, $\mathrm{n}=2$ ). Oxygen consumption (7.1 to $15.8 \mathrm{~L} / \mathrm{min}$ at $\mathrm{F}_{1} \mathrm{O}_{2}$ 100\%) and the Air-Mix mode $\left(\mathrm{F}_{1} \mathrm{O}_{2} 45\right.$ to $\left.86 \%\right)$ differed from one device to the other. Triggering performance was heterogeneous, but several sophisticated ventilators depicted triggering capabilities as efficient as ICU-like ventilators. Pressurization was not adequate for all devices. At baseline, all the ventilators were able to synchronize, but with variations among respiratory conditions. Leak compensation in most ICU-like and 4/10 sophisticated devices was able to correct at least partially for system leaks, but with variations among ventilators.

Conclusion: Major differences were observed between devices and categories, either in terms of general characteristics or technical reliability, across the spectrum of operation. Huge variability of tidal volume delivery with some devices in response to modifications in respiratory mechanics and $\mathrm{F}_{1} \mathrm{O}_{2}$ should make clinicians question their use in the clinical setting.
\end{abstract}

\section{Introduction}

Transportation of critically ill patients requiring mechanical ventilation requires clinical experience, an efficient device, and careful determination of gases [1] and/or electrical resources [2]. Emergency and transport ventilators (ETV) should be technically accurate, and as autonomous as possible.

ETV have become increasingly sophisticated, offering features that were once reserved for the ICU. Noninvasive ventilation (NIV) has become standard during acute respiratory failure in the emergency department (ED) [3] and is now available in most ETV. However, it requires

\footnotetext{
* Correspondence: erwan.Iher@chu-brest.fr

${ }^{1}$ Chaire de Recherche en Médecine d'Urgence, Université Laval/Centre

hospitalier affilié universitaire de Lévis, Québec, Canada

Département de Médecine Familiale et Médecine d'Urgence, Université

Laval, Québec, Canada

Full list of author information is available at the end of the article
}

synchronization of ventilator cycling to respiratory muscles activity, in order to be effective [4-6] and well-tolerated [7]. While NIV availability seems necessary for devices dedicated to acute care [8], it may not be mandatory for transportation solely. A good triggering performance is also mandatory while deep sedation is to be avoided to decrease ventilatory assistance duration.

To our knowledge, while several studies have focused on ETV [9-13], most of them only investigated a few devices. The aims of this study were to provide an objective evaluation of the widest panel of ETV, available in Europe and Northern America. We also aimed to draw standards for an objective choice, taking into account clinicians' specificities of use.

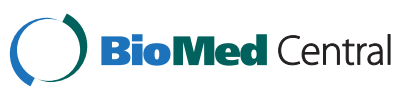

(c) 2014 L'Her et al.; licensee BioMed Central Ltd. This is an Open Access article distributed under the terms of the Creative Commons Attribution License (http://creativecommons.org/licenses/by/4.0), which permits unrestricted use, distribution, and reproduction in any medium, provided the original work is properly credited. The Creative Commons Public Domain Dedication waiver (http://creativecommons.org/publicdomain/zero/1.0/) applies to the data made available in this article, unless otherwise stated. 


\section{Materials and methods General characteristics}

General characteristics (volume, weight, size, noise) were recorded using standardized techniques [14]. Duration of operation from a battery (electrical autonomy) was assessed after two battery charge/discharge cycles, from ventilation initiation to cessation. Gas consumption was evaluated using a filled oxygen cylinder, until effective ventilation cessation. Several devices do not enable precise oxygen inspiratory fraction $\left(\mathrm{FIO}_{2}\right)$ setting, but use an Air-Mix, which produces a specific air-mixing condition using the Venturi effect. The Venturi device within the ventilator is used to entrain a fixed amount of ambient air into a high-pressure oxygen supply, thus resulting in variable $\mathrm{FIO}_{2}$ and gas flow. All autonomy sessions were performed under standardized settings as follows: tidal volume $(\mathrm{VT})=500 \mathrm{~mL}$; respiratory rate $(\mathrm{RR})=15$ breaths (b)/minute; $\mathrm{FIO}_{2}=50 \% /$ Air-Mix and $100 \%$.

\section{Technical performance}

Performance was assessed under three levels of $\mathrm{FIO}_{2}$ $(100 \%, 50 \%$ or Air-Mix, $21 \%)$ and respiratory mechanics combinations as follows: compliance $(C)=30,70$, $120 \mathrm{~mL} / \mathrm{cm} \mathrm{H}_{2} \mathrm{O}$; resistance $(\mathrm{R})=5,10,20 \mathrm{~cm} \mathrm{H}_{2} \mathrm{O} / \mathrm{mL} / \mathrm{s}$. All measures were performed at atmospheric pressure, constant room temperature $\left(22^{\circ} \mathrm{C}\right)$ and test-lung temperature $\left(37^{\circ} \mathrm{C}\right)$, using an $\mathrm{ASL} 5000^{\mathrm{mix}}$ lung simulator (Ingmar, Pittsburgh, PA, USA) [14,15].

\section{Volume delivery and pressurization accuracy}

Volume-controlled ventilation reliability was evaluated at $\mathrm{VT}=500 \mathrm{~mL}, \mathrm{RR}=12 \mathrm{~b} / \mathrm{min}, \mathrm{PEEP}=5$ and $10 \mathrm{~cm}$ $\mathrm{H}_{2} \mathrm{O}$, without inspiratory effort. Pressurization accuracy assessed PEEP stability $\left(\mathrm{PEEP}=10 \mathrm{~cm} \mathrm{H}_{2} \mathrm{O}\right)$ in continuous positive airway pressure (CPAP) mode, and inspiratory pressure (pressure support (PS) $=10 \mathrm{~cm} \mathrm{H}_{2} \mathrm{O}$ ) in the pressure support mode (PSV). For spontaneous breathing, the intensity of effort was quantified by the pressure decrease at $0.1 \mathrm{~s}$, and a single low-effort value was chosen $\left(\mathrm{P} 0.1=2 \mathrm{~cm} \mathrm{H}_{2} \mathrm{O}\right)$. A $10 \%$ variability value for all these parameters was a priori considered clinically relevant for reliability.

\section{Triggering evaluation}

Experimental conditions reproduced those previously reported [16-18], and effort intensity was also set at $\mathrm{PO} .1=2 \mathrm{~cm} \mathrm{H} \mathrm{H}_{2} \mathrm{O}$. Triggering performance was assessed according to the following criteria: 1) triggering delay (DT) between onset of the airway pressure decay and flow delivery; 2) pressurization delay, which is the time at which the airway pressure signal rose (DP), and 3) airway pressure-time product per cycle (PTP) during the trigger phase, defined as the area under the Paw signal during the DT interval. Overall inspiratory delay (DI) is composed of these two components (DT + DP), and a shorter DI indicates better triggering performance.

\section{Asynchrony management}

PSV was delivered at similar respiratory mechanics and P0.1 values, under three levels of circuit leaks ranging from 3.5 to 4.0 (L1), 5.0 to 7.0 (L2) and 9.0 to $12.5 \mathrm{~L} / \mathrm{mi}-$ nute (L3). Leaks were applied using the dedicated ASL5000 module. Asynchrony index (AI) was calculated over a 1-minute period, after signal stabilization, and took into consideration all major types of asynchrony: failed triggering, auto-triggering, prolonged inspiration, multiple triggering, premature and short cycling. Measurements were performed under factory settings for inspiratory time and expiratory trigger without the NIV mode, and then under the NIV mode when available. AI $\geq 10 \%$ of respiratory effort was considered clinically significant [19].

\section{Tested devices}

Twenty-six ETV were compared and a priori classified according to four categories (Tables 1 and 2), taking into account manufacturers' presentation of their devices. ICU-like ETV are devices that, even if transportable, cannot be considered for transportation on a routine basis; sophisticated ETV usually depict curve monitoring screens and allow noninvasive ventilation; simple ETV are standard devices providing no extensive monitoring; mass-casualty/military ETV are devices dedicated for field operations. They are quite heavy and depict little monitoring, but are very robust and may run without oxygen availability.

All ETV were provided free of charge by the manufacturers except three (iVent $201^{\mathrm{Tm}}$, Crossvent $3+{ }^{\mathrm{Tm}}$, and $\mathrm{HT} 50^{\mathrm{mm}}$ ) according to manufacturers' disagreement to enter the evaluation.

\section{Statistical analysis}

Parameters were calculated from $\geq 20$ breaths and are given as mean $\pm \mathrm{SD}$ unless specified otherwise. When adequate, data were compared using analysis of variance (ANOVA) for repeated measures, and the nonparametric Friedman and Wilcoxon ranked tests. A $P$-value $\leq 0.05$ was considered statistically significant. Differences $\geq 10 \%$ were considered clinically significant. Statistical analysis was performed using MedCalc12.7.4 (Ostend, Belgium). For more details about material and methods of measurements, see Additional file 1.

\section{Results}

\section{General characteristics}

ETV characteristics are depicted within Tables 1 and 2 . All 15 ETV within the ICU-like and sophisticated categories (Table 1) had built-in PEEP valves, and most of them 
Table 1 Emergency and transport ventilators' general characteristics (ICU-like and sophisticated)

\begin{tabular}{|c|c|c|c|c|c|c|c|c|c|c|c|c|c|c|c|}
\hline Device & Company & Technology & $\begin{array}{l}\text { Pediatric } \\
\text { use } \\
(\geq 10 \mathrm{~kg})\end{array}$ & $\begin{array}{l}\mathrm{FIO}_{2} \\
\text { (range/\%) }\end{array}$ & Circuit & $\begin{array}{l}\text { Built-in } \\
\text { PEEP }\end{array}$ & $\begin{array}{l}\text { Weight } \\
\text { (kg) }\end{array}$ & $\begin{array}{l}\text { Volume } \\
\left(\mathrm{dm}^{3}\right)\end{array}$ & $\begin{array}{l}\text { Screen } \\
\text { (with curves) }\end{array}$ & $\begin{array}{l}\text { Sonometry } \\
\text { function } \\
\text { (min/max, } \\
\text { dB) }\end{array}$ & $\begin{array}{l}\text { Sonometry } \\
\text { alarm } \\
(\max , \mathrm{dB})\end{array}$ & $\begin{array}{l}\text { Oxygen } \\
\text { consumption } \\
\mathrm{FIO}_{2} 100 \% / \\
50 \% \text { or Air-Mix } \\
\text { (L/min) }\end{array}$ & $\begin{array}{l}\text { Maximal } \\
\text { autonomy } \\
\mathrm{FIO}_{2} 100 \% \\
\text { cylinder E } \\
\text { (min) }\end{array}$ & $\begin{array}{l}\text { Electrical } \\
\text { autonomy } \\
\text { (min) }\end{array}$ & $\begin{array}{l}\text { Market } \\
\text { price } \\
\text { (\$ US) }\end{array}$ \\
\hline \multicolumn{16}{|c|}{ ICU-like emergency and transport ventilators $(n=5)$} \\
\hline Bellavista & $\begin{array}{l}\text { IMT Medical } \\
\text { (Buchs, } \\
\text { Switzerland) }\end{array}$ & Turbine & Yes & $100 \% / 21 \%$ & Mono & Yes & 7.9 & 25.2 & Yes & ND & ND & 13.3/ND & 51 & 75 & $\begin{array}{l}20,000 \text { to } \\
25,000 \text { US } \$\end{array}$ \\
\hline $\mathrm{C} 2$ & $\begin{array}{l}\text { Hamilton } \\
\text { Medical } \\
\text { (Bonaduz, } \\
\text { Switzerland) }\end{array}$ & Turbine & Yes & $100 \% / 21 \%$ & $\begin{array}{l}\text { Mono/ } \\
\text { dual }\end{array}$ & Yes & 9.6 & 29.0 & Yes & $50.4 / 50.6$ & 63.2 & $15.8 / 3.3$ & 43 & 142 & $\begin{array}{l}20,000 \text { to } \\
25,000 \text { US } \$\end{array}$ \\
\hline Servo-i & $\begin{array}{l}\text { Maquet } \\
\text { Getinge } \\
\text { (Göteborg, } \\
\text { Sweden) }\end{array}$ & Pneumatic & Yes & $100 \% / 21 \%$ & Dual & Yes & 20.4 & 39.0 & Yes & $42.1 / 42.6$ & 64.6 & $8.4 / 4.3$ & 81 & 146 & $>25,000$ US $\$$ \\
\hline T75 & $\begin{array}{l}\text { Air Liquide } \\
\text { Medical } \\
\text { Systems } \\
\text { (Antony, } \\
\text { France) }\end{array}$ & Turbine & Yes & 100\%/21\% & $\begin{array}{l}\text { Mono/ } \\
\text { dual }\end{array}$ & Yes & 16.0 & 38.4 & Yes & $48.1 / 50.5$ & 75.7 & $11.1 / 3.5$ & 61 & 200 & $\begin{array}{l}20,000 \text { to } \\
25,000 \text { US } \$\end{array}$ \\
\hline Vela & $\begin{array}{l}\text { Viasys } \\
\text { Carefusion } \\
\text { (San Diego, } \\
\text { Ca, USA) }\end{array}$ & Turbine & Yes & $100 \% / 21 \%$ & Dual & Yes & 17.3 & 28.6 & Yes & $46.5 / 51.5$ & 79.1 & $15.5 / 6.3$ & 44 & 324 & $\begin{array}{l}20,000 \text { to } \\
25,000 \text { US } \$\end{array}$ \\
\hline \multicolumn{16}{|c|}{ Sophisticated emergency and transport ventilators $(n=10)$} \\
\hline $\begin{array}{l}\text { Crossvent } \\
3\end{array}$ & $\begin{array}{l}\text { Bio-Med } \\
\text { Devices } \\
\text { (Guilford, } \\
\text { CT, USA) }\end{array}$ & Pneumatic & Yes & $100 \% / 21 \%$ & Mono & Yes & 4.8 & 6.7 & Yes & $42.7 / 52.4$ & 76.8 & $8.3 / 4.5$ & 82 & 429 & $\begin{array}{l}10,000 \text { to } \\
15,000 \text { US } \$\end{array}$ \\
\hline Elisée & $\begin{array}{l}\text { Resmed } \\
\text { (Saint Priest, } \\
\text { France) }\end{array}$ & Turbine & Yes & 100\%/21\% & $\begin{array}{l}\text { Mono/ } \\
\text { dual }\end{array}$ & Yes & 4.7 & 9.5 & Yes & $47.4 / 52.3$ & 78 & $15 / 3.5$ & 45 & 196 & $\begin{array}{l}10,000 \text { to } \\
15,000 \text { US } \$\end{array}$ \\
\hline HT 50 & $\begin{array}{l}\text { Newport } \\
\text { (Costa } \\
\text { Mesa, CA, } \\
\text { USA) }\end{array}$ & Piston & Yes & $100 \% / 21 \%$ & $\begin{array}{l}\text { Mono/ } \\
\text { dual }\end{array}$ & Yes & 8.3 & 16.6 & No & $42.9 / 48$ & 46.4 & $7.4 / 2.9$ & 92 & $>840$ & $\begin{array}{l}10,000 \text { to } \\
15,000 \text { US } \$\end{array}$ \\
\hline $\begin{array}{l}\text { HT } 70 \\
\text { plus }\end{array}$ & $\begin{array}{l}\text { Newport } \\
\text { Covidien } \\
\text { (Mansfield, } \\
\text { MA, USA) }\end{array}$ & Piston & Yes & 100\%/21\% & $\begin{array}{l}\text { Mono/ } \\
\text { dual }\end{array}$ & Yes & 6.9 & 23.7 & No & $43.8 / 64.7$ & 71.8 & $7.7 / 4.3$ & 88 & 488 & $\begin{array}{l}15,000 \text { to } \\
20,000 \text { US } \$\end{array}$ \\
\hline
\end{tabular}


Table 1 Emergency and transport ventilators' general characteristics (ICU-like and sophisticated) (Continued)

\begin{tabular}{|c|c|c|c|c|c|c|c|c|c|c|c|c|c|c|c|}
\hline iVent 201 & $\begin{array}{l}\text { GE Healthcare } \\
\text { (Cleveland, OH, } \\
\text { USA) }\end{array}$ & Turbine & Yes & $100 \% / 21 \%$ & Mono & Yes & 11.4 & 19.0 & Yes & $51.0 / 56.2$ & 88.5 & $8.9 / 2.6$ & 76 & ND & $\begin{array}{l}20,000 \text { to } \\
25,000 \text { US } \$\end{array}$ \\
\hline LTV 1200 & $\begin{array}{l}\text { Viasys } \\
\text { Carefusion } \\
\text { (San Diego, } \\
\text { Ca, USA) }\end{array}$ & Turbine & Yes & $100 \% / 21 \%$ & Mono & Yes & 6.3 & 5.7 & No & $54.3 / 61.1$ & 80 & $12.6 / 4.3$ & 54 & 127 & $\begin{array}{l}10,000 \text { to } \\
15,000 \text { US } \$\end{array}$ \\
\hline $\begin{array}{l}\text { M. } \\
\text { Transport }\end{array}$ & $\begin{array}{l}\text { Weinmann } \\
\text { (Hamburg, } \\
\text { Germany) }\end{array}$ & Pneumatic & Yes & $100 \% / 40 \%$ & Mono & Yes & 4.8 & 7.0 & Yes & $46.6 / 51.2$ & 56.7 & $7.1 / 2.4$ & 96 & 365 & $\begin{array}{l}15,000 \text { to } \\
20,000 \text { US } \$\end{array}$ \\
\hline $\begin{array}{l}\text { Oxylog } \\
3000\end{array}$ & $\begin{array}{l}\text { Dräger } \\
\text { (Lübeck, } \\
\text { Germany) }\end{array}$ & Pneumatic & Yes & $100 \% / 40 \%$ & Mono & Yes & 5.0 & 8.5 & Yes & $37 / 52.7$ & 49.6 & $7.1 / 2.8$ & 96 & 483 & $\begin{array}{l}15,000 \text { to } \\
20,000 \text { US } \$\end{array}$ \\
\hline T 1 & $\begin{array}{l}\text { Hamilton } \\
\text { Medical } \\
\text { (Bonaduz, } \\
\text { Switzerland) }\end{array}$ & Turbine & Yes & 100\%/21\% & $\begin{array}{l}\text { Mono/ } \\
\text { dual }\end{array}$ & Yes & 6.5 & 19.7 & Yes & ND & 88 & $10.3 / 3.4$ & 66 & 408 & $\begin{array}{l}20,000 \text { to } \\
25,000 \text { US } \$\end{array}$ \\
\hline T 60 & $\begin{array}{l}\text { Air Liquide } \\
\text { Medical } \\
\text { Systems } \\
\text { (Antony, } \\
\text { France) }\end{array}$ & Turbine & Yes & $100 \% / 21 \%$ & $\begin{array}{l}\text { Mono/ } \\
\text { dual }\end{array}$ & Yes & 4.0 & 8.0 & Yes & ND & 79 & $11.1 / 3.8$ & 61 & 384 & $\begin{array}{l}15,000 \text { to } \\
20,000 \text { US } \$\end{array}$ \\
\hline
\end{tabular}

Pediatric use, availability of a pediatric mode; $\mathrm{FIO}_{2}$, oxygen inspiratory fraction (\%); Circuit, type of circuit to be used, monobranched, dual limb, both types; PEEP, positive end expiratory pressure; Volume, the volume of the device was calculated as assimilated to a cube; Sonometry, provides the noise level in function - values are provided without added PEEP and for $\mathrm{FIO}_{2}=100 \%$ for most values, for $\mathrm{FIO} 2=100 \% / 50 \%$ for the two other; Autonomy was evaluated a

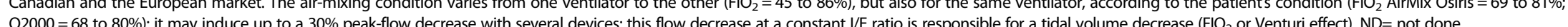


Table 2 Emergency and transport ventilators' general characteristics (simple and mass-casualty/military)

\begin{tabular}{|c|c|c|c|c|c|c|c|c|c|c|c|c|c|c|c|}
\hline Device & Company & Technology & $\begin{array}{l}\text { Pediatric } \\
\text { use } \\
(\geq 10 \mathrm{~kg})\end{array}$ & $\begin{array}{l}\mathrm{FIO}_{2} \\
\text { (range/\%) }\end{array}$ & Circuit & $\begin{array}{l}\text { Built-in } \\
\text { PEEP }\end{array}$ & $\begin{array}{l}\text { Weight } \\
\text { (kg) }\end{array}$ & $\begin{array}{l}\text { Volume } \\
\left(\mathrm{dm}^{3}\right)\end{array}$ & $\begin{array}{l}\text { Screen } \\
\text { (with } \\
\text { curves) }\end{array}$ & $\begin{array}{l}\text { Sonometry } \\
\text { function } \\
\text { (min/max, dB) }\end{array}$ & $\begin{array}{l}\text { Sonometry } \\
\text { alarm (max, dB) }\end{array}$ & $\begin{array}{l}\text { Oxygen } \\
\text { consumption } \\
\mathrm{FIO}_{2} 100 \% / 50 \% \\
\text { or Air-Mix } \\
(\mathrm{L} / \mathrm{min}) \\
\end{array}$ & $\begin{array}{l}\text { Maximal } \\
\text { autonomy } \\
\mathrm{FIO}_{2} 100 \% \\
\text { cylinder E } \\
\text { (min) }\end{array}$ & $\begin{array}{l}\text { Electrical } \\
\text { autonomy } \\
\text { (min) }\end{array}$ & $\begin{array}{l}\text { Market } \\
\text { price } \\
\text { (\$ US) }\end{array}$ \\
\hline \multicolumn{16}{|c|}{ Simple emergency and transport ventilators $(n=9)$} \\
\hline $\begin{array}{l}\text { Autovent } \\
3000\end{array}$ & $\begin{array}{l}\text { Allied } \\
\text { Healthcare } \\
\text { Products } \\
\text { (Saint Louis, } \\
\text { MO, USA) }\end{array}$ & Pneumatic & Yes & $100 \%$ only & Mono & No & 2.8 & 4.8 & No & $47.2 / 48.0$ & 55.3 & $9.7 / \mathrm{NA}$ & 70 & NA & $\begin{array}{l}5,000 \text { to } \\
10,000 \text { US } \$\end{array}$ \\
\hline $\begin{array}{l}\text { Carevent } \\
\text { MRI }\end{array}$ & $\begin{array}{l}\text { O-Two } \\
\text { (Mississauga, } \\
\text { ON, Canada) }\end{array}$ & Pneumatic & Yes & $\begin{array}{l}\text { 100\%/Air- } \\
\text { Mix }\end{array}$ & Mono & Yes & 2.5 & 5.4 & No & 43.2/52.7 & 78.7 & $10.0 / 5.2$ & 68 & NA & $\begin{array}{l}5,000 \text { to } \\
10,000 \text { US } \$\end{array}$ \\
\hline $\begin{array}{l}\text { M. } \\
\text { Standard }\end{array}$ & $\begin{array}{l}\text { Weinmann } \\
\text { (Hamburg, } \\
\text { Germany) }\end{array}$ & Pneumatic & Yes & 100\%/Air-Mix & Mono & No & 1.2 & 4.0 & No & 42.9/44.3 & 49.8 & $8.5 / 3.5$ & 80 & NA & $\begin{array}{l}5,000 \text { to } \\
10,000 \text { US } \$\end{array}$ \\
\hline Osiris 2 & $\begin{array}{l}\text { Air Liquide } \\
\text { Medical } \\
\text { Systems } \\
\text { (Antony, } \\
\text { France) }\end{array}$ & Pneumatic & Yes & 100\%/Air-Mix & Mono & Yes & 5.0 & 9.9 & No & 47.3/53.3 & 83.0 & $11.4 / 5.3$ & 56 & NA & $\begin{array}{l}5,000 \text { to } \\
10,000 \text { US } \$\end{array}$ \\
\hline $\begin{array}{l}\text { Oxylog } \\
2000\end{array}$ & $\begin{array}{l}\text { Dräger } \\
\text { (Lübeck, } \\
\text { Germany) }\end{array}$ & Pneumatic & Yes & 100\%/Air-Mix & Mono & No & 4.3 & 5.3 & No & 46.6/61.6 & 78.8 & $9.4 / 4.7$ & 72 & ND & $\begin{array}{l}5,000 \text { to } \\
10,000 \text { US } \$\end{array}$ \\
\hline $\begin{array}{l}\text { Oxylog } \\
2000+\end{array}$ & Dräger & Pneumatic & Yes & 100\%/Air-Mix & Mono & Yes & 5.4 & 8.4 & Yes & $46.2 / 52.2$ & 77.0 & $7.7 / 2.1$ & 88 & ND & $\begin{array}{l}10,000 \text { to } \\
15,000 \text { US } \$\end{array}$ \\
\hline $\begin{array}{l}\text { ParaPAC } \\
210 \text { D }\end{array}$ & $\begin{array}{l}\text { Smiths } \\
\text { Medical } \\
\text { (Ashford, } \\
\text { UK) }\end{array}$ & Pneumatic & Yes & 100\%/Air-Mix & Mono & No & 3.2 & 3.0 & No & 43.9/45.6 & 56.6 & $8.8 / 3.3$ & 77 & NA & $\begin{array}{l}2,500 \text { to } \\
5,000 \text { US } \$\end{array}$ \\
\hline $\begin{array}{l}\text { ParaPAC } \\
310\end{array}$ & $\begin{array}{l}\text { Smiths } \\
\text { Medical } \\
\text { (Ashford, } \\
\text { UK) }\end{array}$ & Pneumatic & Yes & 100\%/Air-Mix & Mono & Yes & 2.3 & 3.6 & No & ND & ND & ND & ND & NA & $\begin{array}{l}2,500 \text { to } \\
5,000 \text { US } \$\end{array}$ \\
\hline pNeuton & $\begin{array}{l}\text { Airon } \\
\text { (Melbourne, } \\
\text { FL, USA) }\end{array}$ & Pneumatic & No & 100\%/Air-Mix & Mono & Yes & 3.5 & 7.9 & No & $43.4 / 61.3$ & 84.9 & $11.1 / \mathrm{NA}$ & 61 & NA & $\begin{array}{l}5,000 \text { to } \\
10,000 \text { US } \$\end{array}$ \\
\hline
\end{tabular}


Table 2 Emergency and transport ventilators' general characteristics (simple and mass-casualty/military) (Continued)

\begin{tabular}{|c|c|c|c|c|c|c|c|c|c|c|c|c|c|c|c|}
\hline \multicolumn{16}{|c|}{ Mass-casualty and military ventilators $(n=2)$} \\
\hline ComPAC & $\begin{array}{l}\text { Smiths } \\
\text { Medical } \\
\text { (Ashford, UK) }\end{array}$ & $\begin{array}{l}\text { Pneumatic/ } \\
\text { compressor }\end{array}$ & No & $\begin{array}{l}100 \% \mathrm{O}_{2} / \text { Air- } \\
\text { Mix or 100\% } \\
\text { air }\end{array}$ & Mono & No & 11.1 & 18.0 & No & $41.7 / 65.8$ & 42.0 & $7.1 / 2.4$ & 95 & 78 & $\begin{array}{l}5,000 \text { to } \\
10,000 \text { US } \$\end{array}$ \\
\hline MCV100 & $\begin{array}{l}\text { Allied } \\
\text { Healthcare } \\
\text { Products } \\
\text { (Saint Louis, } \\
\text { MO, USA) }\end{array}$ & $\begin{array}{l}\text { Pneumatic/ } \\
\text { compressor }\end{array}$ & No & $\begin{array}{l}\text { Only } 100 \% \mathrm{O}_{2} \\
\text { or 100\% air }\end{array}$ & Mono & No & 6.9 & 9.0 & No & $43.0 / 48.3$ & 61.8 & 7.1/NA & 96 & $298 / 1,142$ & $\begin{array}{l}5,000 \text { to } \\
10,000 \text { US } \$\end{array}$ \\
\hline
\end{tabular}

Pediatric use, availability of a pediatric mode; $\mathrm{FIO}_{2}$, oxygen inspiratory fraction (\%); Circuit, type of circuit to be used, monobranched, dual limb, both types; PEEP, positive end expiratory pressure; Volume, the volume of the device was calculated as assimilated to a cube; Sonometry, provides the noise level in function - values are provided without added $\mathrm{PEEP}$ and for $\mathrm{FIO}_{2}=100 \%$ for most values, for $\mathrm{FIO}=100 \% / 50 \%$ for the two other; Autonomy was evaluated at standardized settings - MCV 100 electrical autonomy has been calculated while using the compressor; Market price has been considered taking into account mean value provided by various distributors on the

Canadian and the European market. The air-mixing condition varies from one ventilator to the other ( $\mathrm{FIO}_{2}=45$ to $86 \%$ ), but also for the same ventilator, according to patient's condition ( $\mathrm{FIO} 2$ AirMix Osiris $=69$ to $81 \%$; $\mathrm{O} 2000=68$ to $80 \%$ ); it may induce up to a $30 \%$ peak-flow decrease with several devices; this flow decrease at a constant $\mathrm{I} / \mathrm{E}$ ratio is responsible for a tidal volume decrease ( $\mathrm{FIO} \mathrm{O}_{2}$ or Venturi effect). $\mathrm{NA}=$ not applicable; $\mathrm{ND}=$ not done. 

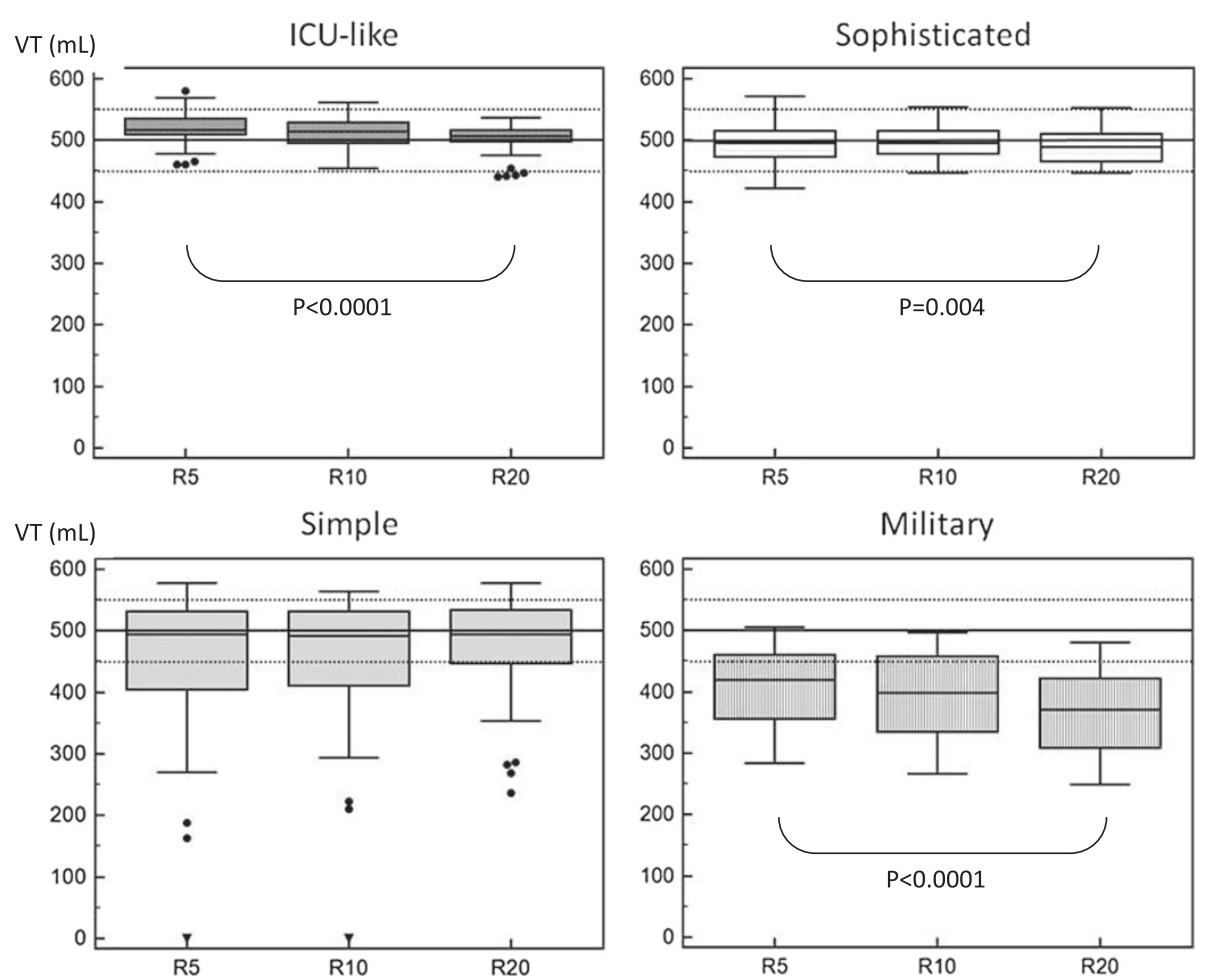

Military

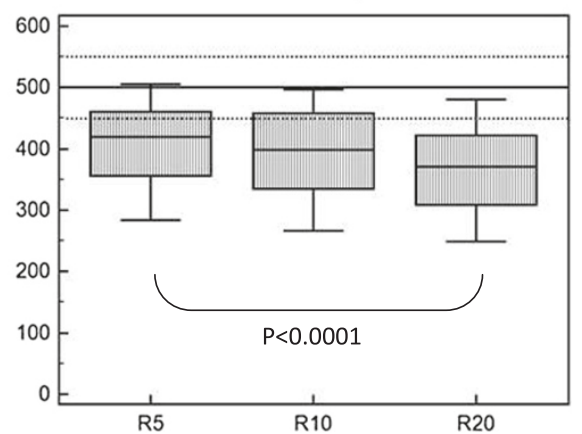

Figure 1 Box plot of tidal volume according to respiratory mechanics variations in the different categories of emergency and transport ventilators (ETV). VT, tidal volume; R, different values of resistance were applied $\left(5,10\right.$ and $\left.20 \mathrm{~cm} \mathrm{H} \mathrm{H}_{2} \mathrm{O} / \mathrm{L} / \mathrm{s}\right)$ in combination with different compliance (30, 70, $120 \mathrm{~cm} \mathrm{H}_{2} \mathrm{O} / \mathrm{L}$ ); dotted line represents the 10\% VT accuracy range; values are provided as mean (95\% Cl) \pm STD; a $P$ value equal to or below 0.05 was considered significant. ICU-like emergency and transport ventilators (ETV; $n=5$ ) are devices that, even if transportable, cannot be considered for transportation on a routine basis; sophisticated ETV $(n=10)$ usually depicts curves monitoring screens and allow noninvasive ventilation; simple ETV $(n=9)$ are standard devices, providing no extensive monitoring; mass-casualty/military ETV $(n=2)$ are devices dedicated for field operations. They are quite heavy, depict little monitoring, but are very robust and may run without oxygen availability. Significant VT variations according to respiratory mechanics changes were observed for all categories, except simple ETV; all ventilators in the ICU-like and sophisticated categories were within the $10 \%$ accuracy range for $\mathrm{VT}$, whereas most in the simple and in the mass-casualty/military category were outside the range.

depicted ventilatory curves on a screen. There were 9/15 (60\%) using a turbine and 2 using a piston to pressurize gases, which means that they were autonomous from medical gases, but dependent on electrical power; $4 / 15$ (27\%) within these categories were pneumatic devices (gas-powered), but they were also dependent on electrical power. Two ETV did not allow $\mathrm{FIO}_{2}$ to decrease below $40 \%$. Other differences in these categories were depicted in terms of oxygen and electrical autonomy, and doublecircuit ventilation availability.

All ventilators within the simple and mass-casualty/ military ETV categories (Table 2) solely enabled the use of monobranched circuits, and only $5 / 11$ had built-in PEEP valves. None enabled $\mathrm{FIO}_{2}$ variations except an Air-Mix condition, which resulted in different $\mathrm{FIO}_{2}$ from one device to the other $\left(\mathrm{FIO}_{2}=45\right.$ to $\left.86 \%\right)$ but also while using a single ETV according to settings and respiratory mechanics. One device only proposed $\mathrm{FIO}_{2}=100 \%$. The mass-casualty/military ETV were dependent on electrical power in the compressor mode, but could use solely compressed gases in case of electrical failure. The volume and market price of these devices was usually lower than that of the two first categories.

\section{Reliability of tidal volume and PEEP delivery Variability according to respiratory mechanics}

All ETV in the ICU-like and sophisticated categories were within the accuracy range for VT, whatever respiratory mechanics combinations, while major deviations were observed in the other categories (Figure 1).

Respiratory mechanics influenced VT delivery in all categories (Figure 1) and for most devices (Figure 2a), except for the simple ETV, but with huge variations between devices.

Of the simple and mass-casualty/military ETV, 6/11 did not provide VT within the $10 \%$ accuracy range (Figure $2 \mathrm{~b}$ ), even for normal respiratory mechanics.

Variability according to $\mathrm{FIO}_{2}$

No effect was observed in the ICU-like and sophisticated ETV categories, while in the simple and mass-casualty/ 

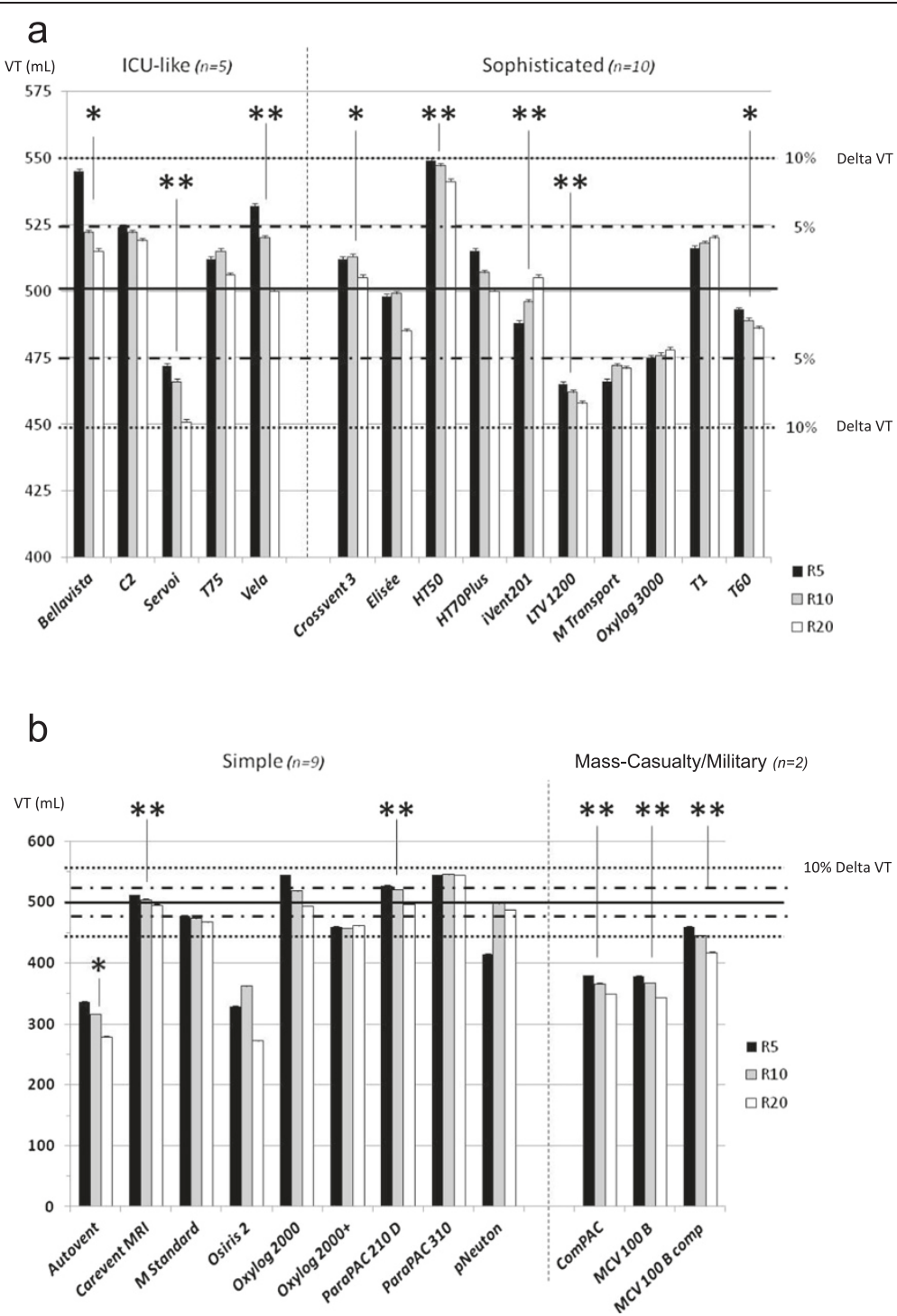

Figure 2 Individual tidal volume delivery according to respiratory mechanics changes. Values are provided as mean $\pm S T D ; V T$, tidal volume; $\mathrm{R}$, different values of resistance were applied $\left(5,10\right.$ and $\left.20 \mathrm{~cm} \mathrm{H} \mathrm{H}_{2} \mathrm{O} / \mathrm{L} / \mathrm{s}\right)$ in combination with different compliance $\left(30,70,120 \mathrm{~cm} \mathrm{H}_{2} \mathrm{O} / \mathrm{L}\right)$; dotted line represents the $10 \%$ accuracy range and the hashed line the $5 \%$ accuracy range; a $P$-value equal to or below 0.05 was considered significant; ${ }^{*} P<0.05 ;{ }^{*} P<0.005$. (a) All ventilators in the ICU-like and sophisticated emergency and transport ventilator (ETV) categories were within the $10 \%$ accuracy range for $V T$, and most of them within the $5 \%$ accuracy range; 8 of 15 ETV depicted an impact of respiratory mechanics changes over VT accuracy; (b) 6 of 11 ventilators in the simple and mass-casualty/military categories developed VT below the 10\% accuracy range, and 6 of them depicted an impact of respiratory mechanics changes over VT accuracy. However, for most of them, the increase in resistance, combined with high compliance, was responsible of a pressure-release safety valve opening (major overdistension related to a low expiratory flow), which meant that they were not able to deliver ventilation.

military categories it induced significant impact on VT for most devices (Figure 3).

\section{PEEP delivery}

Applied PEEP was adequate for most devices in the ICU-like and sophisticated ETV categories, without impact of respiratory mechanics. A huge deviation was observed in the simple ETV category, up to $100 \%$ in several cases (Figure 4).

\section{Triggering evaluation}

No significant difference was observed while comparing ICU-like ETV triggering performances to sophisticated and simple ones $(198 \pm 80$ versus $256 \pm 84$ versus $422 \pm$ $206 \mathrm{~ms}$ respectively; $P=0.18$ ) (Figure 5). 
Pressure-time product per cycle (PTP) during the triggering phase tended to be higher for the simple ETV, as compared to ICU-like and sophisticated ETV $(513 \pm 247$ versus $133 \pm 119$ versus $154 \pm 103 \mathrm{~cm} \mathrm{H}_{2} \mathrm{O}$ ms respectively; $P=0.08)$. However, few data are available for simple ETV, while ventilation was often impossible for most respiratory mechanics combinations, without any triggered ventilatory cycles, even for some devices that were presumed to allow spontaneous ventilation.

\section{Pressurization and NIV mode performance}

Of the ETV, 15/26 (58\%) were presumed to allow NIV, of which 4/15 (27\%) did not provide PS reliability, whatever respiratory mechanics and leaks (Figure 6).

Leak increases did not modify the AI for ICU-like ETV, while it influenced efficiency for three sophisticated ETV (Figure 7). For all ICU-like ETV except one, the NIV mode enabled an AI decrease $<10 \%$. Huge heterogeneity of the NIV-mode effect was observed within the sophisticated ETV category.

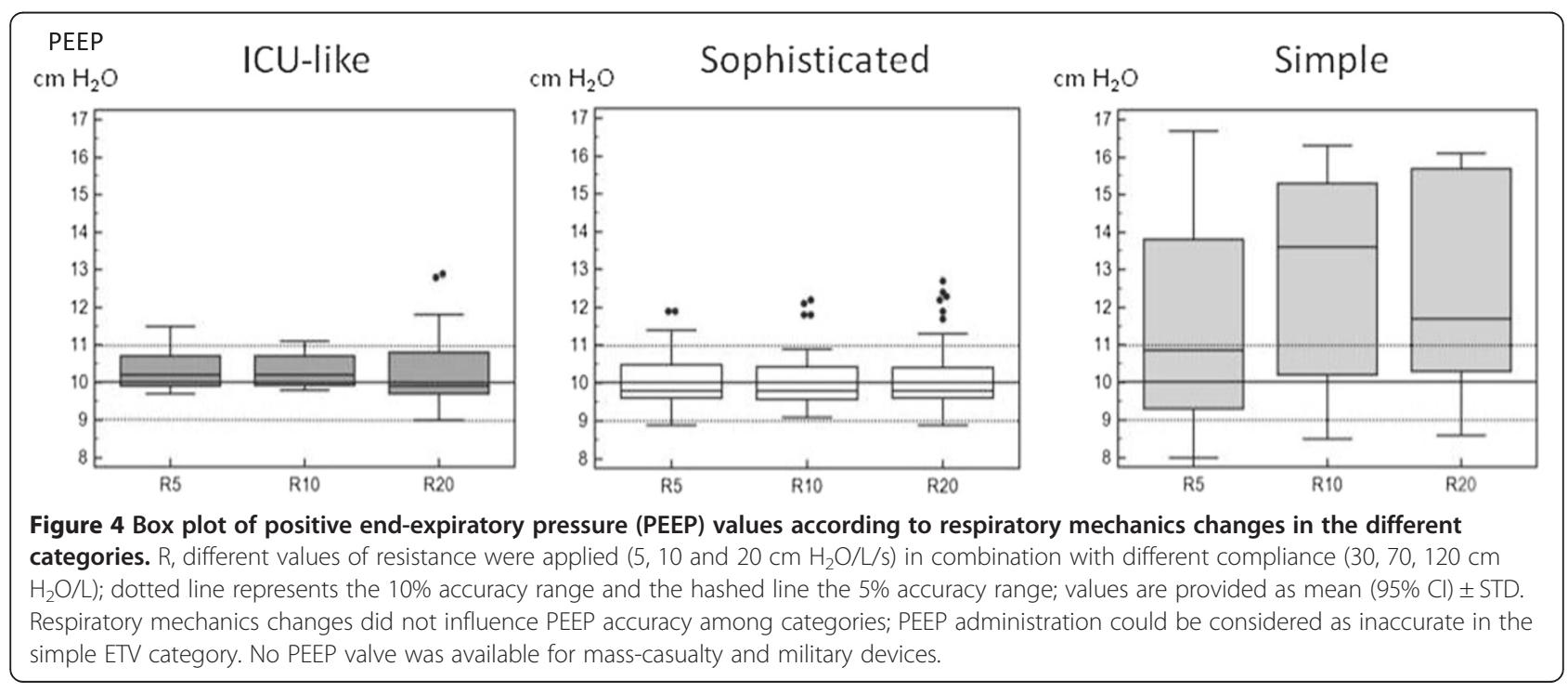




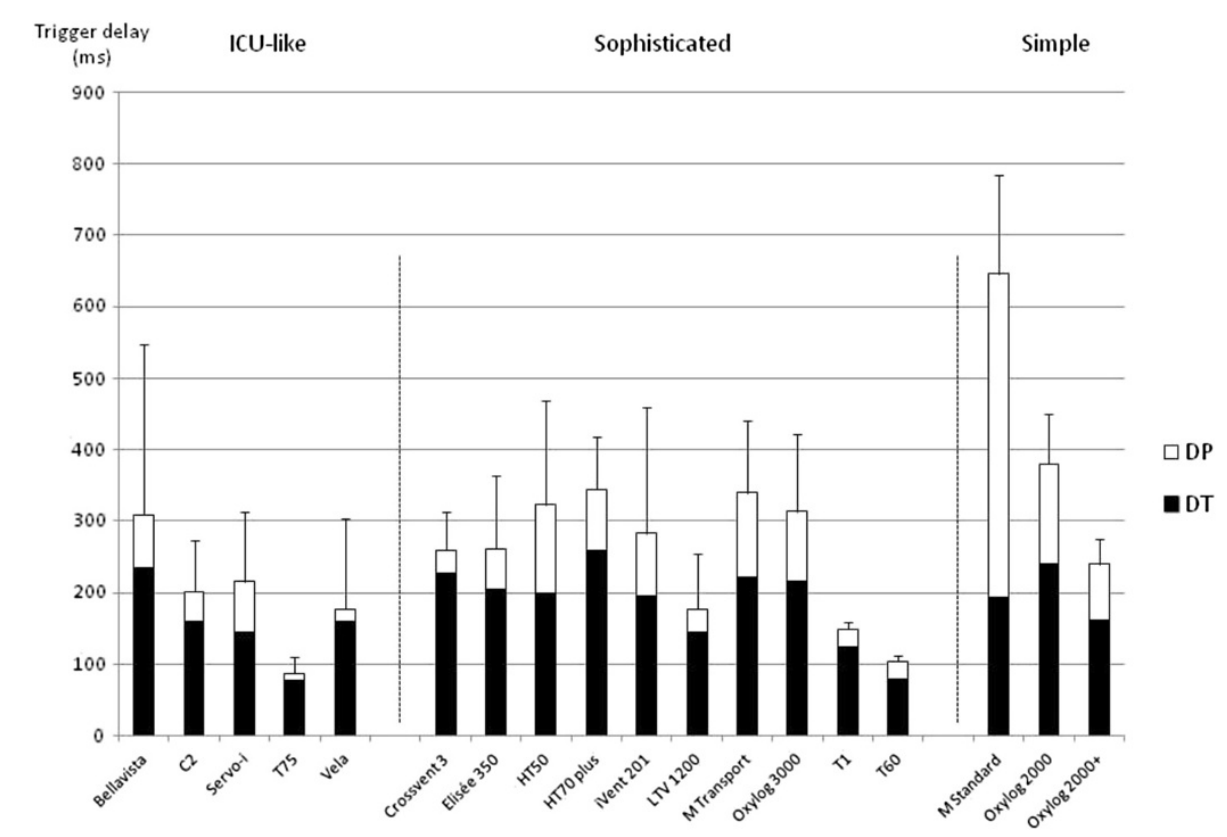

Figure 5 Individual triggering values among all respiratory mechanics combinations. Values are provided as mean \pm STD; DT, triggering delay between onset of the airway pressure decay and flow delivery; DP, pressurization delay, which is the time at which the airway pressure signal rose; overall inspiratory delay (DI) is composed of these two components (DT + DP), and a shorter DI value indicates better trigger performance. Significant differences could be exhibited in terms of triggering performances while comparing one ETV category to the other.

\section{Discussion}

This study allowed the comparison of a large panel of ETV, under a wide range of simulated clinical conditions. It depicts major differences between categories, but also between devices in a similar category, in terms of general characteristics and technical performance across the entire spectrum of operation. This objective comparison may enable clinicians to adapt their choice of devices according to the setting of the operation of the devices.

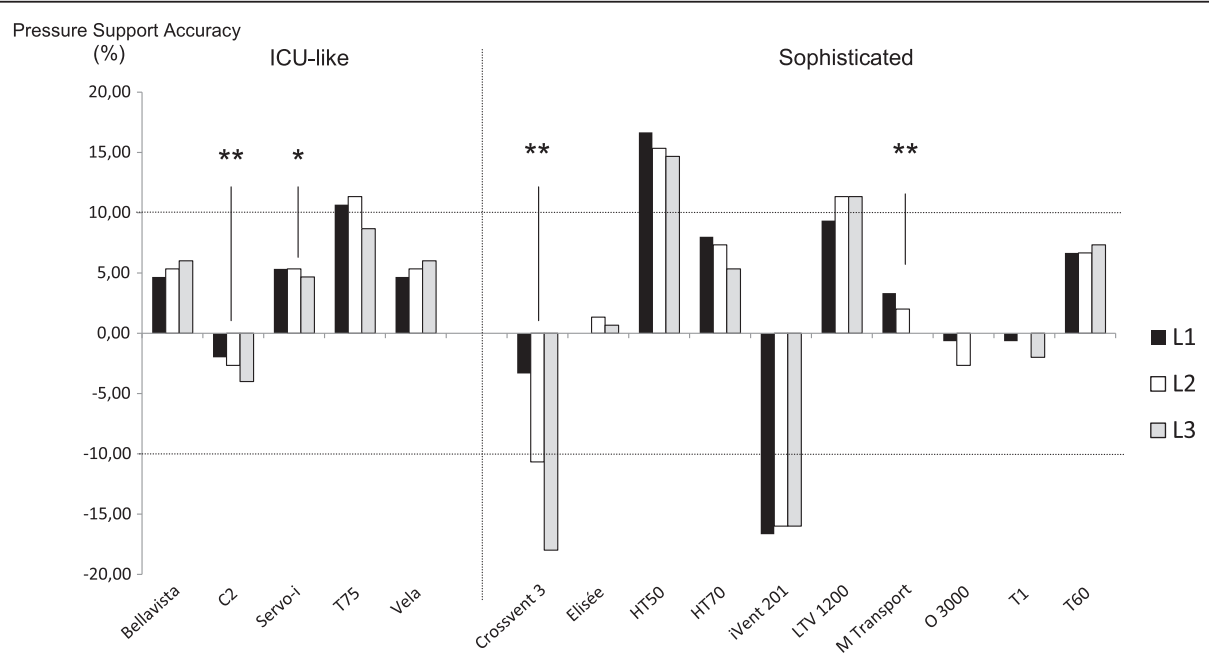

Figure 6 Pressure support accuracy under different levels of leaks. Values are provided as \% difference as compared to settings (pressure

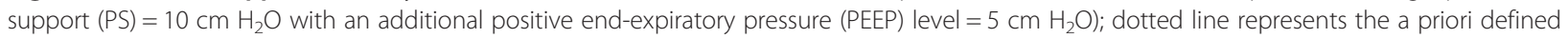
accuracy range $( \pm 10 \%)$; three levels of leaks were used: $L 1=3.5$ to $4.0 \mathrm{~L} /$ minute; $L 2=5.0$ to $7.0 \mathrm{~L} /$ minute; $\mathrm{L} 3=9.0$ to $12.5 \mathrm{~L} /$ minute. Several devices were quite insensitive to leaks, with PS variation near zero; statistical analysis evaluated the impact of leaks over PS accuracy and a $P$-value equal to or below 0.05 was considered significant; ${ }^{*} P<0.05 ;{ }^{* *} P<0.005$. Of the ETV, 10/15 provided PS within an accuracy range equal to or less than $10 \%$. If 4/15 ETV were statistically influenced by leaks, only one might be considered as influenced with a clinical relevance, the other one being within the accuracy range. 


\section{General characteristics}

Major differences were observed in terms of weight and volume, and ICU-like ETV seemed dedicated to use within ICUs and/or for intra-hospital transportation of severely ill patients, but not for standard out-of-hospital transport. The inclusion of the Servo-i in our testing can be discussed given its general characteristics (especially volumetry and weight), but it is positioned by the company as a portable ventilator and therefore falls into the ICU-like category.

There are mainly two categories of devices according to the technology they use to provide ventilation. Pneumatic ventilators use compressed oxygen and the other uses an electrically powered turbine to generate pressure. The performance of the second seems to be similar to those of ICU ventilators, but they are dependent on battery life [12]. A third, but less frequent option exists, the compressor or piston-driven ventilator, which represents
4/26 devices of our panel and these are also electrically powered. This technology can be combined with another technology to increase autonomy (mass-casualty/military).

Oxygen consumption differed between devices, which means that a calculation taking into account minute ventilation and oxygen availability within the canister might not be adequate. Simple ETV oxygen consumption was lower, but this could be related to the fact that they only allowed Air-Mix. Air-Mixing differed in terms of performance from one device to the other $\left(\mathrm{FIO}_{2}=45\right.$ to $86 \%$, but also for a single device $\left(\mathrm{FIO}_{2}=68\right.$ to $80 \%$ with the Oxylog2000) according to respiratory mechanics and ventilation parameters, that is, oxygen consumption and hypoxemia correction may vary within a huge range, without any information provided to the clinician.

Battery duration is an important function of ETV, as it determines autonomy in environments where electricity is not available $[2,20]$. Such concerns about electrical 
power autonomy and battery duration mainly focus on the ICU-like and sophisticated ETV, whereas simple ones will mainly be concerned by gas consumption. As already investigated, battery duration differed within devices [2,11,13]. The American Association for Respiratory Care guidelines recommend a battery duration $\geq 4$ hours for portable ventilators in pandemic and mass-casualty conditions [21]. To our knowledge, no guideline exists for standard ETV, but except for ICU-like ETV, two out of three devices had battery duration $\geq 4$ hours. Several variables affect battery duration, including ventilator operating characteristics, whereas our evaluation was performed using a single setting. Turbinedriven ventilators are known to have a shorter battery duration than piston-driven ventilators, and constant-speed turbines use the most energy [22,23].

Noise is a frequent environmental pollutant in the hospital setting, especially within ED and ICUs. The World Health Organization (WHO) recommends that the background noise in hospitals should not exceed 30 decibels $(\mathrm{dB})$, and that peaks during night should be $<40 \mathrm{~dB}$ [24], but it has been demonstrated that average levels are usually higher within ICUs (60 to $70 \mathrm{~dB}$; peaks $\geq 90 \mathrm{~dB}$ ) [25]. Studies using polysomnography and environmental measurements to determine whether noise could explain irregular sleep patterns in ICU patients have reported that it caused 11 to $17 \%$ of arousals and awakenings [26]. Sleep disruption in the ICU is also associated with increased requirement for anxiety treatments [27] and biochemical markers of stress [28]. In our study, the average sonometry varied from $37 \mathrm{~dB}$ to $59 \mathrm{~dB}$, thus, clearly crossing the WHO recommendation, but also the more realistic $45-\mathrm{dB}$ limit chosen by neonatologists [29]. These results are similar to those obtained in bench testing of handy ventilators [14]. Noise measurements are rarely available for the ED [30], but it may also be considered that more stressful levels of noise may occur during transportation [31], especially when using helicopters.

\section{Tidal volume accuracy}

No data are ever provided by the industry within the specification documents about the potential impact of respiratory mechanics over technical performance/accuracy towards parameters settings. When looking at the simple devices as an example, it seems interesting from the clinician point of view that the Parapac 201 which is quite a cheap device is accurate in terms of VT accuracy whatever respiratory mechanics, while a contrario, $40 \%$ of the set VT is not delivered with the Autovent. Moreover, and this could be considered as the main purpose of the study, such independent bench-testing really enables us to compare a large panel of devices on the same technical basis.

\section{Triggering evaluation}

PSV is a partial ventilatory support during which substantial muscle activity remains, and the effort required to trigger the ventilator represents 10 to $30 \%$ of the breathing effort [16]. Lung-model studies of oldergeneration demand-valve systems reported values for DT in excess of $400 \mathrm{~ms}$, even at maximal sensitivity [16]. These triggering values can be superimposed on what we observed in our study with the simple ETV. It is now considered that ICU ventilators may have a DT $\leq 60 \mathrm{~ms}[17,32]$.

The triggering performance was heterogeneous among ETV, and mean DT values tended to be higher than those obtained in other studies [12,18]. However this may be related to the application of a wider range of respiratory mechanics combination $(R=5$ to $20 \mathrm{~cm}$ $\mathrm{H}_{2} \mathrm{O} / \mathrm{mL} / \mathrm{s} ; \mathrm{C}=30$ to $120 \mathrm{~cm} \mathrm{H}_{2} \mathrm{O}$ ). When comparing the same experimental conditions, results of ICU-like ETV do fall within range. Several sophisticated ETV depicted triggering capabilities as efficient as most ICUlike ventilators.

Patient effort to trigger (expressed as PTP) is relatively constant with increasing ventilator support. As demonstrated by Richard et al., a minor increase in P0.1 (2 versus $4 \mathrm{~cm} \mathrm{H}_{2} \mathrm{O}$ ) may result in a higher pressure fall and thus, a higher inspiratory effort [18]. Our simulation model confirms that most new generation ICU-like and sophisticated ETV induces low effort to trigger, while simple ETV (even the most recent devices that are presumed to enable CPAP), were not adequate for such a purpose.

\section{Pressurization and NIV modes}

PSV is widely used during acute respiratory failure [33]. As observed by various authors, most ETV were able to maintain adequate PEEP and PS, even when there was a minimal to moderate leak [34]. However, clinicians may be aware that several devices within the sophisticated ETV category did not enable adequate pressurization with up to $-18 \%$ PS delivery. This default was accentuated by leaks for one device, while such variations were lower and/or always within the acceptable range for the others. Leaks may increase patient effort and asynchrony from the ventilator, but the available NIV modes usually correct that deficiency, at least in recent ICU ventilators [35].

At baseline, all the ventilators were able to synchronize without failed triggering or auto-triggering. A study previously reported wide variations in terms of synchronization capability between devices [36]. Failed triggering more frequently occurred in chronic obstructive pulmonary disease (COPD) respiratory mechanics conditions and longer times were required to stabilize VTs, as compared to acute respiratory distress syndrome (ARDS) conditions. The T60 was the only ventilator to maintain synchrony in 
all scenarios, without any adjustment of sensitivity, inspiratory termination criteria, and/or NIV mode setting. However, the leak compensation of most ICU-like and 4/10 sophisticated ETV was able to correct partially or completely for system leak interferences, but with a wide variation among ventilators, as already depicted [37]. As the manufacturers have not revealed the exact triggering and cycling algorithms used during system leaks, it is difficult to explain discrepancies among the different studies.

\section{Limitations of the study}

Several limitations of our study may be discussed. The primary limitation is that comparing a technically sophisticated ICU-like device that costs as much as $\$ 25,000$ to another one below $\$ 10,000$ could be considered as making no sense. For this sake, devices have been divided within several categories. However, as depicted at least between ICU-like and sophisticated categories, such bench testing also demonstrates that several cheaper devices do perform at least equally to more sophisticated and expensive ones. Moreover, comparison between devices within a similar category also enables us to depict important differences in terms of performance. A second limitation is that the study was performed on a mechanical model, which can never mimic all complexities of the interactions between a patient and a ventilator, raising the question of clinical relevance. The ASL5000 has two characteristics that make it different from patients and from the typical dualchamber mechanical models: 1) it does not simulate expiratory efforts; 2) the Pmus profile in the ASL5000 is not modified by pressurization during the inspiratory phase. However, the bench simulated all possible situations and combinations that can be encountered in the clinical field. A final limitation could be that in some patients with acute respiratory failure, ventilatory efforts may be higher than that of our simulated efforts.

\section{Conclusion}

We provided a wide evaluation of ETV ventilators on most general features and technical aspects of these devices. Clinicians should be aware of the significant differences that were found among these ventilators when choosing these important devices for initial management and transport of critically ill patients. As expected, huge heterogeneity in terms of general characteristics and performance were observed. We should be questioned about the great variability in terms of VT delivery with several specific devices and the fact that ETV performance might be greatly influenced by lung mechanics. NIV capabilities are also highly modified by leaks and their own NIV-mode efficiency. Such a bench-test comparison may also enable the industry to improve its products.

\section{Key messages}

- Major differences can be observed between ETV devices and categories in terms of general characteristics and/or technical reliability

- Variability of VT delivery with some ETV across the spectrum of operations should raise questions from clinicians about their use

- The technical performance of most ETV is influenced by lung mechanics

- Triggering and leak compensation performance are crucial issues while performing noninvasive ventilation

- Several new-generation ETV may be considered as more efficient than ICU ventilators for most clinical situations

\section{Additional file}

Additional file 1: provides detailed information about material and methods.

\section{Abbreviations}

Al: the global asynchrony index between the simulated patient and the ventilator; Air-Mix: design of a specific air-mixing condition using the Venturi effect resulting in variable oxygen inspiratory fraction; ARDS: acute respiratory distress syndrome; COPD: chronic obstructive pulmonary disease; CPAP: continuous positive airway pressure; $\mathrm{dB}$ : decibel; DI: overall inspiratory delay, composed of the two trigger components (trigger delay + pressurization delay); DP: pressurization delay, which is the time at which the airway pressure signal rose; DT: triggering delay between onset of the airway pressure decay and flow delivery; ED: emergency department; ETV: emergency and transport ventilators; $\mathrm{FIO}_{2}$ : oxygen inspiratory fraction, which is a parameter for the neuro-muscular activation of the respiratory system, an important determinant for the work of breathing; NIV: noninvasive ventilation; P0.1: the negative airway pressure generated during the first 100 msec of an occluded inspiration; PEEP: positive end-expiratory pressure; Pmus: simulated patient's respiratory muscle effort intensity; PS: pressure support; PSV: pressure support ventilation; PTP: the airway pressure-time product per cycle during the trigger phase; RR: respiratory rate; VT: tidal volume; WHO: World Health Organization.

\section{Competing interests}

Erwan L'HER is or has been consultant for Air Liquide Medical Systems and Maquet, and is the co-founder of Oxy'nov Inc., a spin-off company from the university Laval-Québec, dedicated to automation in critical care. Nicolas Marjanovic has received honorarium from Weinmann for a lecture. Annie Roy has no conflicts of interest. This work was funded in part by the Chaire de Recherche en Médecine d'Urgence Hôtel-Dieu de Lévis/Université Laval.

\section{Authors' contributions}

ELH designed the study, performed the evaluations, analyzed the results and wrote the article; AR and NM performed the evaluations, analyzed the results and helped to draft the manuscript. All authors read and approved the final manuscript.

\section{Acknowledgements}

ELH wishes to acknowledge the help of Dr François Lellouche from the Institut Universitaire de Cardiologie et de Pneumologie de Québec for its help while conceiving the performance tests during the Canadian winter! The authors wish to acknowledge the constant implication and motivation of respiratory therapists and emergency physicians from the Hôtel-Dieu de Lévis, and the medical staff from Brest University Hospital that allowed performance of the 
ergonomy and user-friendly evaluation. They also wish to acknowledge the help of manufacturers who kindly provided their devices free of charge.

\section{Author details}

'Chaire de Recherche en Médecine d'Urgence, Université Laval/Centre hospitalier affilié universitaire de Lévis, Québec, Canada. ${ }^{2}$ Département de Médecine Familiale et Médecine d'Urgence, Université Laval, Québec, Canada. ${ }^{3}$ Centre de Recherche du Centre hospitalier affilié universitaire de Lévis et CHA Enfant-Jésus, Québec, Canada. ${ }^{4}$ Pôle Urgences-SAMU, CHU de la Cavale Blanche, 29609 Brest Cedex, France. ${ }^{5}$ Centre de Simulation en Santé, LATIM, INSERM UMR 1101, Université de Bretagne Occidentale, 29200 Brest, France. ${ }^{6}$ Réanimation Médicale et Urgences Adultes, $\mathrm{CHU}$ de la Cavale Blanche, Brest Cedex, France.

Received: 12 May 2014 Accepted: 22 August 2014

Published online: 15 October 2014

\section{References}

1. Blakeman TC, Rodriquez D, Branson RD: Accuracy of the oxygen cylinder duration calculator of the LTV-1000 portable ventilator. Respir Care 2009, 54:1183-1186

2. Blakeman TC, Robinson BRH, Branson RD: Battery performance of 4 intensive care ventilator models. Respir Care 2010, 55:317-321.

3. L'Her E: Noninvasive ventilation outside the intensive care unit: a new standard of care? Crit Care Med 2005, 33:1642-1643.

4. Marini JJ, Rodriguez RM, Lamb V: The inspiratory workload of patientinitiated mechanical ventilation. Am Rev Respir Dis 1986, 134:902-909.

5. Maclntyre NR, Ho Ll: Effects of initial flow rate and breath termination criteria on pressure support ventilation. Chest 1991, 99:134-138.

6. Elliott MW, Mulvey DA, Moxham J, Green M, Branthwaite MA: Inspiratory muscle effort during nasal intermittent positive pressure ventilation in patients with chronic obstructive airways disease. Anaesthesia 1993, 48:8-13.

7. Jubran A, Van de Graaff WB, Tobin MJ: Variability of patient-ventilator interaction with pressure support ventilation in patients with chronic obstructive pulmonary disease. Am J Respir Crit Care Med 1995, 152:129-136.

8. Austin PN, Campbell RS, Johannigman JA, Branson RD: Work of breathing characteristics of seven portable ventilators. Resuscitation 2001, 49:159-167.

9. Waydhas C: Intrahospital transport of critically ill patients. Crit Care Lond Engl 1999, 3:R83-R89.

10. Zanetta G, Robert D, Guérin C: Evaluation of ventilators used during transport of ICU patients - a bench study. Intensive Care Med 2002, 28:443-451.

11. Chipman DW, Caramez MP, Miyoshi E, Kratohvil JP, Kacmarek RM: Performance comparison of 15 transport ventilators. Respir Care 2007, 52:740-751

12. Boussen S, Gainnier M, Michelet P: Evaluation of ventilators used during transport of critically ill patients: a bench study. Respir Care 2013, 58:1911-1922.

13. Blakeman TC, Branson RD: Evaluation of 4 new generation portable ventilators. Respir Care 2013, 58:264-272.

14. L'Her E, Roy A: Bench tests of simple, handy ventilators for pandemics: performance, autonomy, and ergonomy. Respir Care 2011, 56:751-760.

15. Ferreira JC, Chipman DW, Kacmarek RM: Trigger performance of mid-level ICU mechanical ventilators during assisted ventilation: a bench study. Intensive Care Med 2008, 34:1669-1675.

16. Aslanian P, El Atrous S, Isabey D, Valente E, Corsi D, Harf A, Lemaire F, Brochard $\mathrm{L}$ : Effects of flow triggering on breathing effort during partial ventilatory support. Am J Respir Crit Care Med 1998, 157:135-143.

17. Thille AW, Lyazidi A, Richard J-CM, Galia F, Brochard L: A bench study of intensive-care-unit ventilators: new versus old and turbine-based versus compressed gas-based ventilators. Intensive Care Med 2009, 35:1368-1376.

18. Richard J-C, Carlucci A, Breton L, Langlais N, Jaber S, Maggiore S, Fougère S, Harf A, Brochard L: Bench testing of pressure support ventilation with three different generations of ventilators. Intensive Care Med 2002, 28:1049-1057

19. Thille AW, Rodriguez P, Cabello B, Lellouche F, Brochard L: Patient-ventilator asynchrony during assisted mechanical ventilation. Intensive Care Med 2006, 32:1515-1522.
20. Falaize L, Leroux K, Prigent H, Louis B, Khirani S, Orlikowski D, Fauroux B, Lofaso F: Battery life of portable home ventilators: effects of the ventilatory settings. Respir Care 2013.

21. American Association of Respiratory Care: Guidelines for Acquisition of Ventilators to Meet Demands for Pandemic Flu and Mass Casualty Incidents. Including addendum \#1 (June 5, 2006) and addendum \#2 (January 30, 2008). 2006, [https://www.aarc.org/resources/vent_guidelines_08.pdf]

22. Campbell RS, Johannigman JA, Branson RD, Austin PN, Matacia G, Banks GR: Battery duration of portable ventilators: effects of control variable, positive end-expiratory pressure, and inspired oxygen concentration. Respir Care 2002, 47:1173-1183.

23. Rodriquez D Jr, Branson R, Barnes SA, Johannigman JA: Battery life of the "four-hour" lithium ion battery of the LTV-1000 under varying workloads. Mil Med 2008, 173:792-795.

24. Berglund B, Lindvall T, Schwela D: Guidelines for Community Noise. Geneva: World Health Organization; 1999.

25. Darbyshire $J L$, Young JD: An investigation of sound levels on intensive care units with reference to the WHO guidelines. Crit Care Lond Engl 2013, 17:R187.

26. Gabor JY, Cooper AB, Crombach SA, Lee B, Kadikar N, Bettger HE, Hanly PJ: Contribution of the intensive care unit environment to sleep disruption in mechanically ventilated patients and healthy subjects. Am J Respir Crit Care Med 2003, 167:708-715.

27. De Miranda S, Pochard F, Chaize M, Megarbane B, Cuvelier A, Bele N, Gonzalez-Bermejo J, Aboab J, Lautrette A, Lemiale V, Roche N, Thirion M, Chevret S, Schlemmer B, Similowski T, Azoulay E: Postintensive care unit psychological burden in patients with chronic obstructive pulmonary disease and informal caregivers: A multicenter study. Crit Care Med 2011, 39:112-118

28. Hu R, Jiang $X$, Zeng $Y$, Chen X, Zhang $Y$ : Effects of earplugs and eye masks on nocturnal sleep, melatonin and cortisol in a simulated intensive care unit environment. Crit Care Lond Engl 2010, 14:R66.

29. Information on Levels of Environmental Noise Requisite to Protect Public Health and Welfare with an Adequate Margin of Safety: Government Printing Office. Washington, DC: Environmental Protection Agency, Office of Noise Abatement and Control; 1974.

30. Ratnapalan S, Cieslak P, Mizzi T, McEvoy J, Mounstephen W: Physicians' perceptions of background noise in a pediatric emergency department. Pediatr Emerg Care 2011, 27:826-833.

31. Price TG, Goldsmith LJ: Changes in hearing acuity in ambulance personnel. Prehospital Emerg Care Off J Natl Assoc EMS Physicians Natl Assoc State EMS Dir 1998, 2:308-311.

32. Sassoon CS: Triggering of the ventilator in patient-ventilator interactions. Respir Care 2011, 56:39-51.

33. Brochard L: Pressure support ventilation. In Princ Pract Mech Vent. Edited by Tobin MJ. New York: MacGraw-Hill; 1994:239-257.

34. Ueno $Y$, Nakanishi N, Oto J, Imanaka H, Nishimura M: A bench study of the effects of leak on ventilator performance during noninvasive ventilation. Respir Care 2011, 56:1758-1764

35. Vignaux $L$, Tassaux $D$, Jolliet $P$ : Performance of noninvasive ventilation modes on ICU ventilators during pressure support: a bench model study. Intensive Care Med 2007, 33:1444-1451.

36. Oto J, Chenelle CT, Marchese AD, Kacmarek RM: A comparison of leak compensation in acute care ventilators during noninvasive and invasive ventilation: a lung model study. Respir Care 2013, 58:2027-2037.

37. Vignaux L, Tassaux D, Carteaux G, Roeseler J, Piquilloud L, Brochard L, Jolliet P: Performance of noninvasive ventilation algorithms on ICU ventilators during pressure support: a clinical study. Intensive Care Med 2010, 36:2053-2059.

doi:10.1186/s13054-014-0506-0

Cite this article as: L'Her et al:: Bench-test comparison of 26 emergency and transport ventilators. Critical Care 2014 18:506. 